\title{
Discretion without Accountability: Politics, Flood Damage, and Climate
}

\author{
By Mary W. Downton ${ }^{1}$ and Roger A. Pielke Jr. ${ }^{2}$
}

\begin{abstract}
Federal disaster assistance is one component of U.S. policy for coping with damaging floods. The president ultimately determines whether or not federal relief is provided to states and local communities following a disaster. Yet, guidelines governing the president's discretion are vague and the total federal cost of disaster assistance is extremely difficult to determine. This study analyzes flood-related presidential disaster declarations from 1965 to 1997. It compares the annual number of flood-related declarations to measures of precipitation and flood damage, finding that presidents have differed significantly in disaster declaration policy. Annual differences in declarations during seven presidential administrations do not correspond to the president's political party affiliation. In addition, a state's ability to pay has not been a major consideration in presidential decisions about whether a disaster warrants federal assistance. However, presidential decisions are related to whether or not the president is running for reelection. Declarations are also related to changes in legislative and administrative policy. This paper discusses the significance of these findings in the context of national policies governing floods and other disasters.
\end{abstract}

\section{INTRODUCTION}

A presidential declaration of major disaster or emergency is the key action that makes federal disaster relief available to states, local governments, businesses, and individuals affected by disasters. Policymakers and hazards experts alike have expressed concern over the dramatic increase in the number of declarations and federal disaster expenditures over the last two decades [e.g., General Accounting Office (GAO) $(1995,1996)$ and Platt (1999)].

A majority of presidential disaster declarations are related to floods. Some have suggested that changes in climate have contributed to an increase in the frequency and cost of floods and other natural disasters, as did James Lee Witt, Director of the Federal Emergency Management Agency (FEMA), at a news conference in November 1998: "Regardless of whether you believe the cause is global warming or natural changes in weather patterns, there is no disagreement that the frequency and severity of what we call 'weather events' are on the rise" (Witt 1998). [In a joint news conference in April 2000, Witt and National Oceanic and Atmospheric Administration (NOAA) Administrator D. James Baker made a similar set of claims (NOAA 2000).]

In the case of floods, the role attributed to climate appears to be supported by evidence of increasing precipitation in the United States, particularly in "extreme" daily precipitation events (Karl and Knight 1998). At the same time, there is apparently conflicting evidence that maxi-

${ }^{1}$ Assoc. Sci., Nat. Ctr. for Atmospheric Res., P.O. Box 3000, Boulder, CO 80307. E-mail: downton@ucar.edu

${ }^{2}$ Dir., Center for Science and Technology Policy Research, University of Colorado, Boulder, CO 80309. E-mail: pielke@ cires.colorado.edu

Note. Discussion open until April 1, 2002. To extend the closing date one month, a written request must be filed with the ASCE Manager of Journals. The manuscript for this paper was submitted for review and possible publication on November 6, 2000; revised April 17, 2001. This paper is part of the Natural Hazards Review, Vol. 2, No. 4, November, 2001. (C)ASCE, ISSN 1527-6988/01/0004-0157-0166/ $\$ 8.00+\$ .50$ per page. Paper No. 22181. mum streamflows have not increased (Lins and Slack 1999). Recent research helps to clarify this issue: flood damage is statistically related to precipitation, and the relationship is strengthened if population growth is taken into account, but even so precipitation explains a relatively small amount of the interannual variability and overall growth in U.S. flood damage (Pielke and Downton 1999, 2000). Thus, to explain increasing damage one needs to look at factors beyond simply that of climate.

One such factor underlying increasing flood damage is government policies, including federal disaster policy [Burby et al. 1999; Association of State Floodplain Managers (ASFPM) 2000]. Federal disaster assistance is a part of the nation's strategy for copying with damaging floods, and its availability influences community, state, and other federal decisions about flood prevention and mitigation. Therefore, the nation's flood and disaster policies are inextricably tied together.

Under disaster legislation since 1950, most federal assistance in disasters is contingent upon a presidential disaster declaration, and is predicated on a finding that federal assistance is required to supplement state and local capabilities. Federal implementation of disaster assistance policy has been inconsistent, in part, because there has been little basis for judging the capabilities of state and local governments to meet relief needs (May 1985; Platt 1999).

This paper examines presidential discretion in disaster declarations that involved floods during 1965-1997. The investigation proceeds as follows:

1. Determine how the number of flood-related declarations have differed between presidential administrations, using statistical models to control for annual variations in flood damage and precipitation.

2. Investigate the possible influence of electoral politics by comparing flood-related declarations in years 
when the president faces reelection with those in other years.

3. Examine the relationship between flood-related disaster declarations and several measures of states' economic capabilities to respond to disasters on their own (i.e., "ability to pay").

4. Consider legislative, administrative, and political factors that might have affected the number of disaster declarations issued during each administration.

The present paper concludes with a discussion of broader implications of the analysis for federal disaster policy.

\section{CHANGING FEDERAL RESPONSE TO DISASTERS}

Until 1950, states and localities typically coped with disasters without federal help, though after occasional major catastrophes Congress passed special legislation to provide financial assistance. The Disaster Relief Act of 1950 established, for the first time, a basis for the systematic provision of federal assistance to states and local governments in disasters that might occur anywhere in the country. The first such declaration was issued by President Eisenhower in 1953.

The federal role has grown through acts of Congress, administrative actions, and changes in public expectations (Mileti 1999). Between 1950 and 1979, Congress expanded the scope of allowable benefits, vastly enlarging federal disaster assistance functions under a multitude of agencies and programs (May 1985). In 1979, President Carter established FEMA by executive order to consolidate and coordinate disaster response efforts. In the early 1980s, FEMA went through frequent reorganizations as a succession of directors strove to form a cohesive agency and formulate an agenda for guiding federal, state, and local emergency preparedness activities (May 1985).

The Robert T. Stafford Disaster Relief and Emergency Assistance Act (PL 100-707), adopted in 1988, broadened the president's discretion in judging what does or does not qualify as a circumstance requiring a disaster declaration. Hurricane Andrew in 1992 and the Midwest floods in 1993 led Congress to broaden FEMA's mission to include risk reduction and hazard mitigation (FEMA 1997). In the wake of disasters of the 1990s, FEMA's capabilities expanded. The expectation, by state governments and the public, of large-scale federal assistance grew accordingly, to the point that federal assistance in disasters is now regarded by many as an entitlement, even in relatively minor events (Burby 1991; Platt 1999).

\section{PRESIDENTIAL DISCRETION AND ACCOUNTABILITY}

As the federal role has expanded, one constant persists: eligibility for most federal disaster relief hinges on a presidential declaration of major disaster or emergency. The legislative and administrative guidelines governing the president's decision are virtually the same under the Stafford Act as they were in 1950, worded in general terms to assure presidential discretion in responding quickly to catastrophe.

Fiscal accountability for presidential disaster decisions would require that records be available to explain what has been done and to enumerate the funds that have been spent. Yet, the full costs associated with federal disaster assistance are unknown, or at least not readily available. Assistance is provided in many forms by many federal agencies and not tracked in a comprehensive or consistent manner (Heinz Center 2000). Hence, the role of presidential discretion is not subject to the usual scrutiny imposed on most other government activities. A broader accountability would require explicit statement of the goals of federal disaster programs and evaluation of their cost and effectiveness.

For a state or local community to qualify for federal benefits, the governor must formally request assistance. FEMA makes a recommendation and then the president must decide whether to declare a major disaster or emergency. In declaring a disaster, the president follows no specific set of objective criteria; rather, each event or incident is evaluated on its own merits (Sylves 1998). Indeed, members of Congress and local governments have opposed attempts by FEMA to establish consistent criteria (Burby 1991; FEMA 1999; Platt 1999). The Stafford Act specifically prohibits the use of an "arithmetic formula or sliding scale" to deny assistance to any "geographic area" (PL 100-707, sec. 320). According to the federal General Accounting Office (GAO 1995), declaration decisions are not "supported by standard factual data or related to published criteria."

How, then, can presidents' disaster declaration decisions be compared and evaluated? In the absence of published policies and criteria, one can examine the historical record of declarations in their broader context. From May 1953 to May 1997, 1,941 gubernatorial requests for presidential declaration of major disaster or emergency resulted in 1,299 presidential approvals (67\%). Fig. 1 shows the average annual number of requests and approvals under each presidential administration in that period (Sylves 1998, Table 2-A). Requests soared during the Nixon and Carter administrations, then plummeted during the Reagan administration. Does this imply that the number or seriousness of catastrophic events increased during the Nixon and Carter years and decreased during the Reagan years? Not necessarily, because the number of gubernatorial requests is affected by many other factors. Requests, turndowns, and approvals are all influenced by the presidential administration, which provides the structure and context in which governors' requests are submitted.

The number of gubernatorial requests that were specifically related to floods is not readily available. Therefore, the present study initially focuses on the number of floodrelated declarations that were approved by each president. Requests are reexamined in a later discussion. 


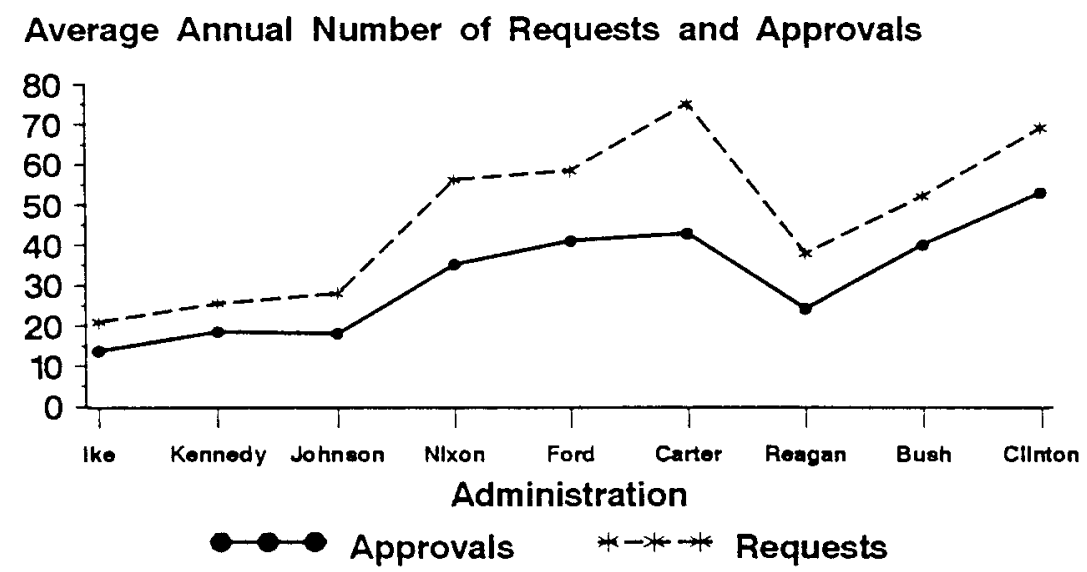

FIG. 1. Presidential Declarations of Major Disaster and Emergency, by Presidential Administration, May 1953-May 1997 (Data Source: Sylves 1998)

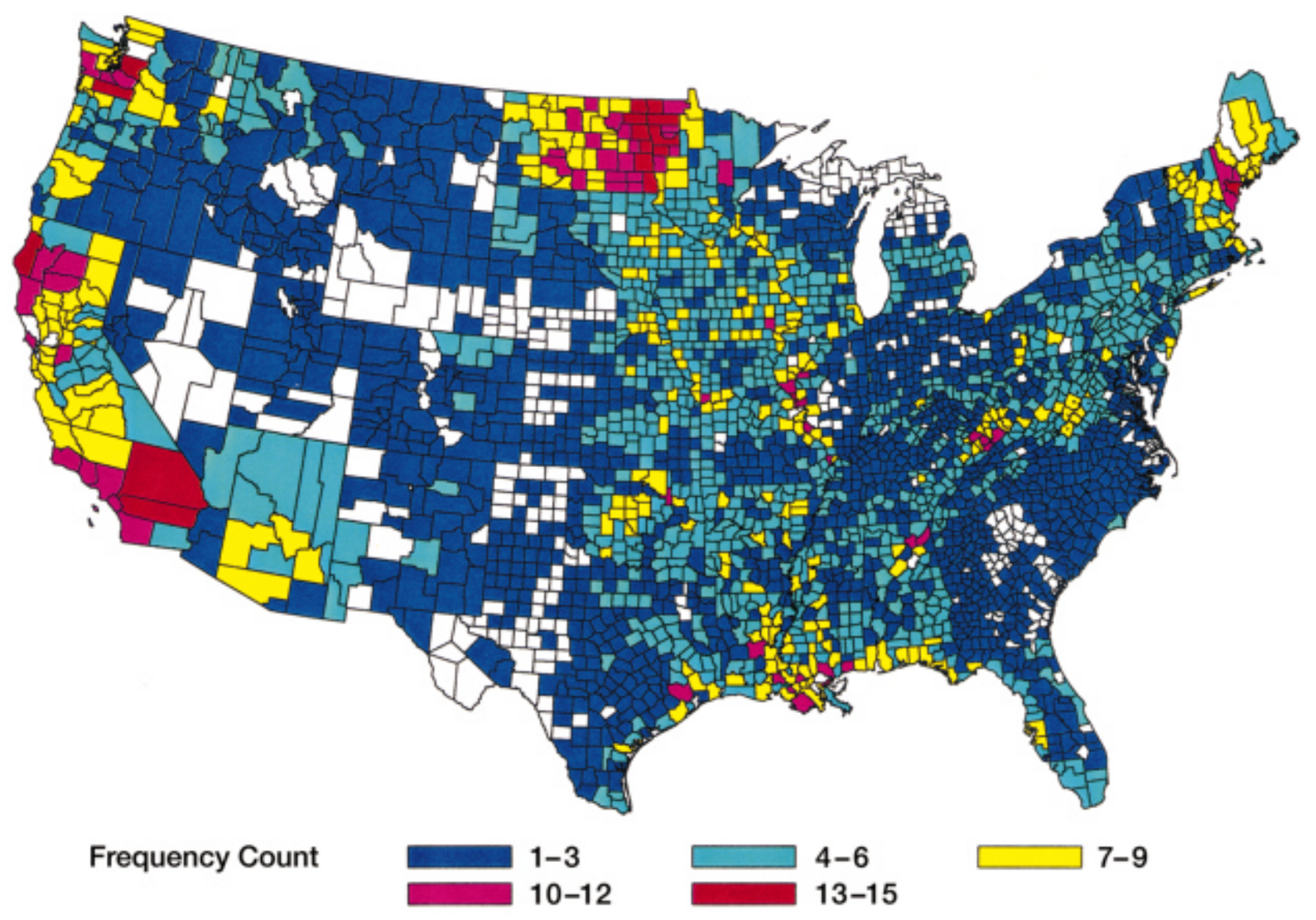

FIG. 2. Presidential Disaster Declarations Involving Floods, by County, December 24, 1964-March 3, 1998

\section{FLOOD-RELATED DISASTER DECLARATIONS}

FEMA classifies disaster declarations by "primary incident type." Many of the 18 types are unrelated to flooding (e.g., earthquake, volcano, fire). The "flood" and "flood and tornado" incident types accounted for 56\% of all presidential declarations and over $35 \%$ of federal disaster relief spending between May 1953 and May 1997 (Sylves 1998).

For this study, FEMA provided a complete list of the counties included in all flood- or hurricane-related disaster declarations from December 24, 1964 to March 3, 1998
(M. Buckley, personal communication, July 1998). Floodrelated disasters are defined to include all declarations of "flood," "flood and tornado," "severe storm," "coastal storm," and "dam/levee break" types, because these incidents typically involve flooding as a major cause of damage. Large flood losses are occasionally associated with low-intensity hurricanes; therefore, disasters of "hurricane" type were screened to include only tropical storms and Category 1 hurricanes, plus declarations in the aftermath of three major hurricanes that caused large-scale flooding as they slowed (Pielke and Landsea 1998). 


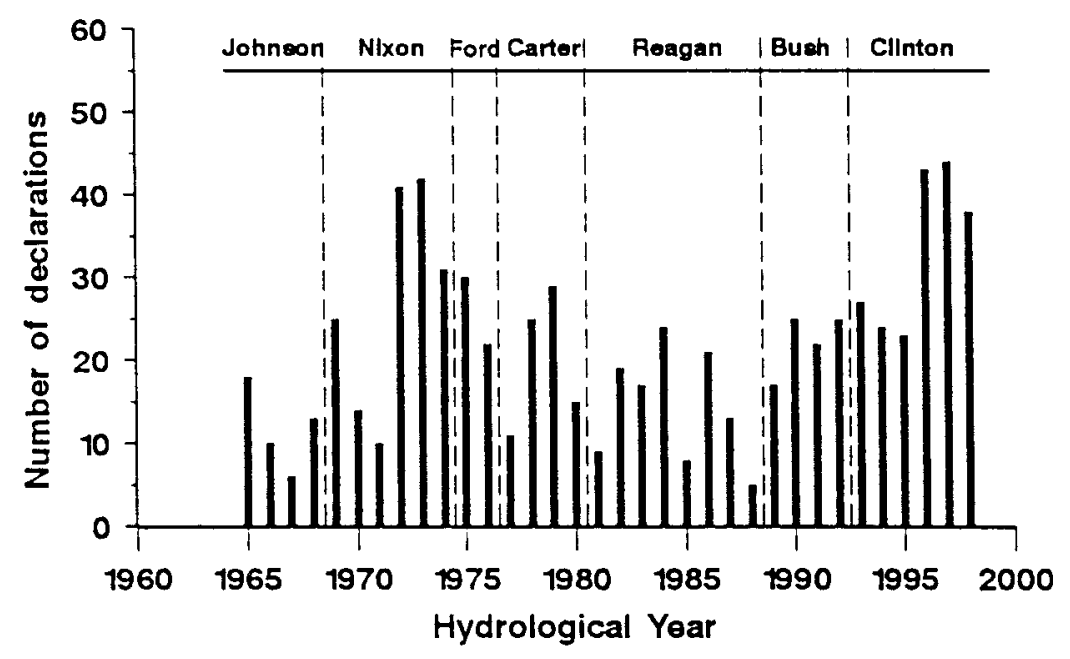

FIG. 3. Number of Presidential Disaster Declarations Involving Floods in Each Fiscal Year, 1965-1998

A declaration of major disaster or emergency is issued to a state, within which one or more counties are declared eligible for federal assistance. Fig. 2 shows the counties included in flood-related disaster declarations between December 24, 1964 and March 3, 1998. Rhode Island is the only state with no flood-related declarations, and most U.S. counties $(86 \%)$ were designated at least once. (The four largest islands of Hawaii and 11 of Alaska's districts were also included in flood-related declarations during this period.) Frequent flood-related disasters (10 or more per county) occurred in much of North Dakota and in large regions of Minnesota, Washington, and California. Texas and California received the largest number of floodrelated disaster declarations, with 38 and 32 declarations, respectively.

Most disaster declarations apply to only a small part of a state. Of the 720 flood-related declarations in the author's database, $84(12 \%)$ involved just one county. Over half of the declarations covered $<15 \%$ of the counties in a state, and only six declarations covered an entire state. The portion of a state included in disaster declarations by each president ranged from a median of $9 \%$ of counties under the Reagan Administration to 20\% under the Clinton Administration.

In this study, data are compiled by federal fiscal year, e.g., 1991 refers to October 1, 1990 through September 30, 1991. The fiscal year corresponds well with the annual hydrologic cycle, because precipitation is generally lowest in the fall, so floods seldom span two fiscal years. Disaster declarations are recorded by "action date," and can therefore be accurately attributed to a presidential administration. Most declarations are issued within a week or two after a major disaster because of strong pressure for an immediate public sector response. (Because action dates lag slightly behind actual flood dates, the disaster declarations for fiscal year $y$ are counted from October 15 of year $y-1$ to October 14 of year $y$.)

Fig. 3 shows the number of flood-related disaster declarations in each fiscal year of 1965-1998 (in Fig. 3, the counts for the 1998 fiscal year were completed using flood-related disaster declarations for March-September 1998 obtained from the FEMA Web site), with presidential administrations indicated.

\section{FLOOD DAMAGE AND PRECIPITATION}

When the president decides whether or not to approve a particular disaster declaration request, the actual extent of the damage is uncertain. The decision is based, in part, on initial damage estimates submitted by local, state, and federal officials. For this study, it was considered important to have early estimates of flood losses from an independent source to compare with the disaster declarations.

The National Weather Service (NWS) has been collecting flood loss estimates since 1903 through its network of field offices. The estimates cover significant flooding events and include only direct damage due to flooding that results from rainfall or snowmelt. They do not include flooding due to winds, such as hurricane storm surges. They cover public and private direct costs, but exclude indirect costs such as temporary housing or unemployment. The estimates are obtained from local sources, usually within 3 months after a flood event, and have no direct connection to disaster assistance requests (F. Richards, personal communication, Feb. 2000).

[The authors are nearing completion of a project (NOAA \#N96AGP0451) to reanalyze and evaluate the NWS flood damage data. The reanalyzed data are used in this study and will be presented in a forthcoming report. The NWS data are considered the best available nationwide estimates of direct damage due to flooding. Researchers have significant concerns about the comprehensiveness of the data; however, FEMA, NWS, and the Federal Interagency Floodplain Management Task Force (FIFMTF) have each concluded that the data are of sufficient quality to be used for large-scale trend analysis (FIFMTF 1992; FEMA 1997), and the authors' reanalysis supports that conclusion.]

NWS estimates of U.S. annual damage during fiscal 
years 1932-1997, adjusted for inflation are shown in Fig. 4. Flood damage estimates are adjusted to 1995 dollars using an implicit price deflator based on the U.S. gross domestic product. Reliable estimates for the years 19801982 were unavailable, so those years are excluded from this analysis. Extremely high damage occurred in 1972, when tropical storm Agnes lashed the East Coast, and in 1993, when months of flooding devastated a nine-state region of the upper Mississippi basin. The effects of local weather variability are reflected in these damage figures, as are effects of increasing population, wealth, and development. National population, shown by a dashed line in Fig. 4, is one factor responsible for the increasing trend in flood damage (Pielke and Downton 2000).

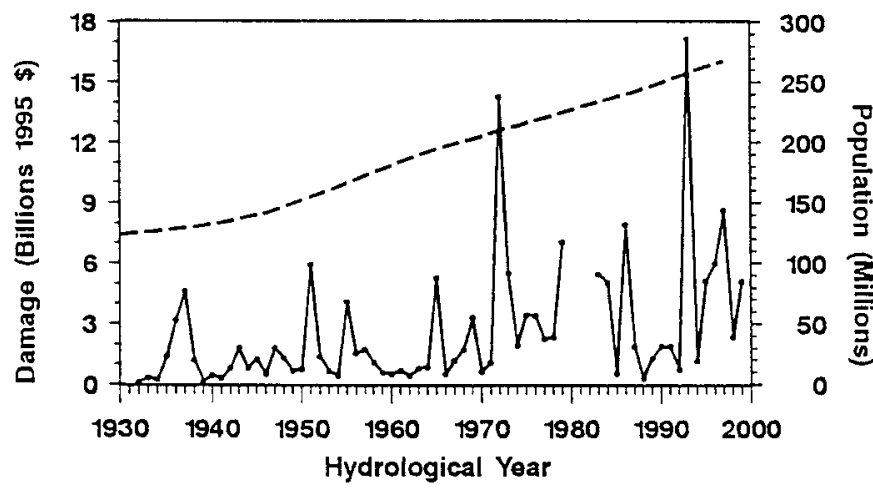

FIG. 4. Estimated U.S. Flood Damage Adjusted for Inflation (Solid Line) and Population (Dashed Line), by Fiscal Year, 1932-1999

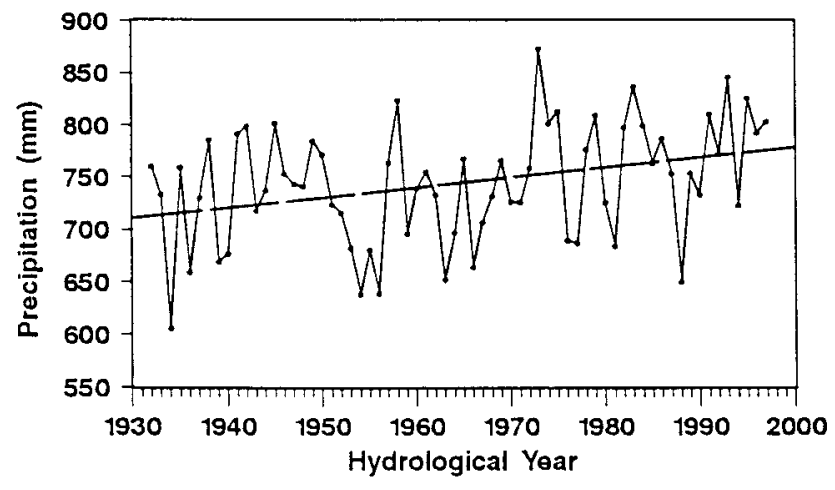

FIG. 5. U.S. Annual Total Precipitation, 1932-1997
Precipitation change is another factor contributing to increasing flood damage; therefore, total annual precipitation is included in the analysis. Annual precipitation, averaged over the conterminous United States, is shown in Fig. 5. [The Illinois State Water Survey provided the precipitation data (K. E. Kunkel, personal communication Jan. 1998)]. It is somewhat correlated with flood damage and shows a statistically significant increasing trend during 1932-1997 (Pielke and Downton 2000). The notable peak in 1973 coincides with severe floods in the lower Mississippi basin.

\section{PRESIDENTIAL DISCRETION: COMPARISON OF ADMINISTRATIONS}

Table 1 shows the mean annual disaster declarations, flood damage, and precipitation during each presidential administration. President Clinton issued the most floodrelated declarations per year and included the most counties. Can this be explained by the fact that flood damage and precipitation were also at their highest levels during his administration? Not entirely, as will be seen below.

To compare presidents' responses to flood disasters, one should consider differences in the incidence of damaging floods during each administration. For example, differences between the Reagan and Bush Administrations can be seen in Table 1. (Throughout this paper, "Bush Administration" refers to that of George H. W. Bush, 19891992). Mean flood damage was lowest during the Bush Administration, yet the numbers of disaster declarations and counties included were substantially higher under Bush than under Reagan. This suggests that policies related to disaster declarations might have differed between the two administrations.

The authors use analysis of covariance techniques to test whether the seven presidential administrations differed significantly in number of disaster declarations, using precipitation and damage as covariates to control for differences in the incidence of damaging floods.

Commonly used statistical techniques require that data be normally distributed and have homogeneous variance. For the analyses below, frequency distributions of the data series were tested for normality, and transformations were

TABLE 1. Mean Annual Flood-Related Disaster Declarations, Flood Damage, and Precipitation, in Fiscal Years 1965-1979 and 1983-1997 by Presidential Administration

\begin{tabular}{|c|c|c|c|c|c|c|}
\hline \multirow[b]{2}{*}{ President } & \multirow[b]{2}{*}{ Fiscal years } & \multirow[b]{2}{*}{$N$} & \multicolumn{4}{|c|}{ Annual Means in Each Administration } \\
\hline & & & $\begin{array}{c}\text { Disaster } \\
\text { declarations }\end{array}$ & $\begin{array}{l}\text { Counties } \\
\text { included }\end{array}$ & $\begin{array}{c}\text { Damage } \\
\text { (millions of } \\
1995 \text { dollars) }\end{array}$ & $\begin{array}{l}\text { Precipitation } \\
(\mathrm{mm})\end{array}$ \\
\hline Johnson & $1965-1968$ & 4 & 11.8 & 190 & 2,164 & 717 \\
\hline Nixon & 1969-1974 & 6 & 27.2 & 393 & 4,448 & 775 \\
\hline Ford & $1975-1976$ & 2 & 26.0 & 251 & 3,414 & 751 \\
\hline Carter & $1977-1979$ & 3 & 21.7 & 211 & 3,884 & 758 \\
\hline Reagan & $1983-1988$ & 6 & 14.7 & 160 & 3,507 & 765 \\
\hline Bush & 1989-1992 & 4 & 22.3 & 357 & 1,445 & 767 \\
\hline Clinton & $1993-1997$ & 5 & 32.2 & 603 & 7,603 & 798 \\
\hline \multirow[t]{2}{*}{ All years } & $1965-1979$ & 30 & 22.2 & 322 & 3,955 & 765 \\
\hline & $1983-1997$ & & & & & \\
\hline
\end{tabular}

${ }^{\mathrm{a}}$ Fiscal years 1980-1982 are omitted because reliable flood damage estimates are unavailable. 
TABLE 2. Number of Flood-Related Disaster Declarations, Adjusted for Flood Damage and Precipitation, by Administration

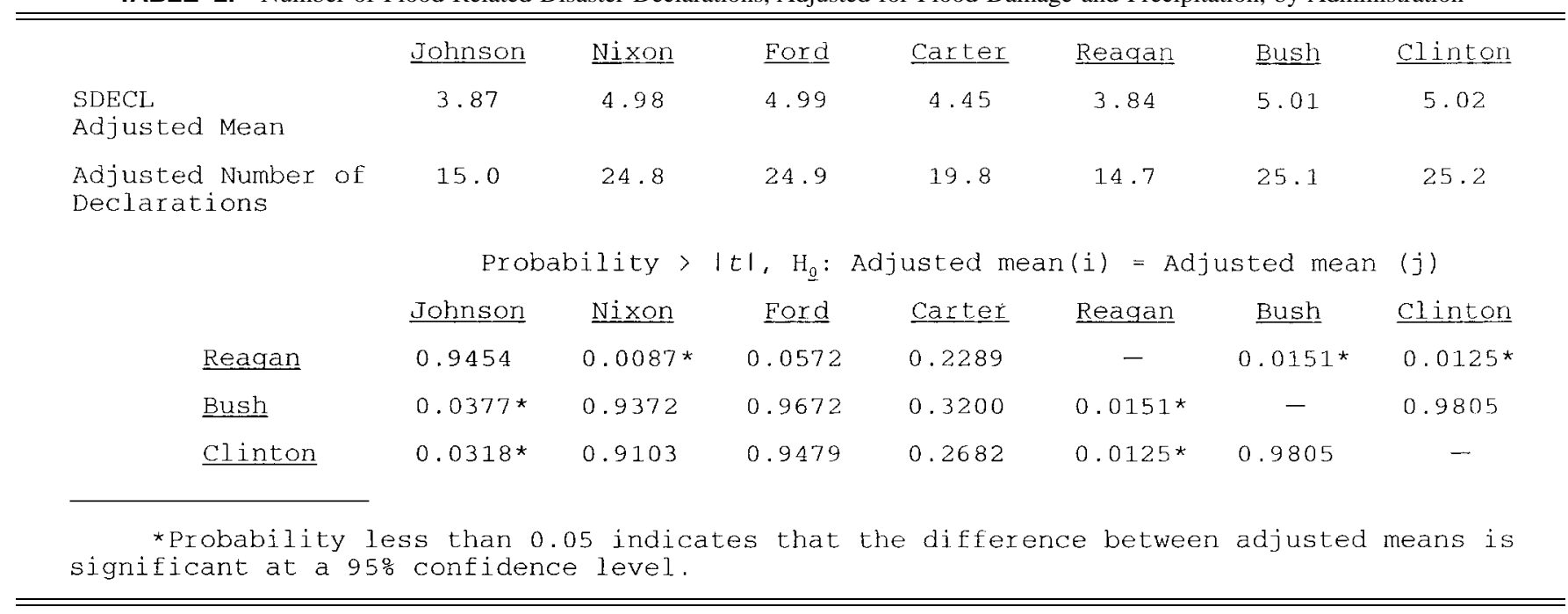

applied to the disaster and flood damage data to approximate normal distributions with reasonably homogeneous variance, creating the following measures: $S D E C L=S q r t$ (number of flood-related disaster declarations); and $L D=$ $\log$ (damage), where damage is measured in billions of constant 1995 dollars. One data series did not require transformation: $T P=$ total annual precipitation $(\mathrm{mm})$. A classification variable was created to differentiate between administrations: ADMIN = index of the seven administrations, 1965-1997 ( $A=$ Johnson, $\ldots, G=$ Clinton, in alphabetical order).

The number of flood-related declarations each year is statistically related to both flood damage and precipitation (correlations are $r=0.71$ between SDECL and $L D$, and $r$ $=0.68$ between SDECL and TP). To establish a baseline for comparison, a multiple regression model was fit using flood damage and precipitation as predictors of the number of declarations. Both are significant, and the coefficient of determination in this "baseline model" is $R^{2}=$ 0.572 .

When presidential administration (ADMIN) is added to the baseline model, it is statistically significant and increases $R^{2}$ to 0.763 . Analysis of covariance shows that, after adjusting for annual variations in flood damage and precipitation, one can reject the hypothesis that mean annual numbers of flood-related declarations have been essentially the same under the seven administrations $(F=$ $\left.2.81, d f_{1}=6, d f_{2}=21, p=0.036\right)$. Thus, differences in the number of declarations are not simply a result of coincidental differences in the incidence of damaging floods during a president's term of office.

Table 2 shows how the administrations have differed in their response to damaging floods. The authors are particularly interested in the records of the most recent presidents: Reagan, Bush, and Clinton. After adjustment for annual variations of flood damage and precipitation, declarations under Bush and Clinton are nearly equal (because flood damage was low during the Bush Administration and high during the Clinton Administration).
Pairwise comparisons in Table 2 show which differences are statistically significant: President Reagan issued significantly fewer flood-related declarations than Presidents Nixon, Bush, and Clinton; President Clinton issued significantly more flood-related declarations than Presidents Johnson and Reagan.

Though official disaster policies of these administrations are unclear, it is concluded that the outcomes (in terms of numbers of disaster declarations) were significantly different in the Reagan Administration than in the Nixon, Bush, and Clinton Administrations. The distinctions do not follow party lines: Republican Reagan and Democrat Johnson issued relatively few declarations, while Democrat Clinton joined Republicans Nixon, Ford, and Bush in generously issuing declarations.

\section{ROLE OF ELECTORAL POLITICS: PRESIDENTIAL DISCRETION IN REELECTION YEARS}

Some observers have suggested that presidents and other officials are inclined to manipulate disaster declarations to serve their own political needs. Platt (1999) asserts, "Ultimately, the decision as to whether or not to issue a declaration is a political choice by the president, often influenced by congressional and media attention." May (1985) compared the proportion of disaster declaration requests that were approved in election years with those in nonelection years under Presidents Nixon, Ford, and Carter. He found an "election year effect" during the Nixon presidency, with statistically higher approval rates in the 1972 presidential election year than in nonelection years. (In contrast, President Carter had a slightly lower approval rate in the 1980 presidential election year than in nonelection years.) However, May's study was limited by lack of adjustment for the severity of disasters.

In the present study an election year effect is tested adjusting for precipitation and the severity of damaging floods. Analysis of covariance is used to compare numbers of flood-related declarations in years when a president was 
seeking reelection with numbers in all other years. The authors' fiscal years (October through September) correspond reasonably well to the period leading up to the November election. Reelection campaigns occurred in fiscal years 1972 (Nixon), 1976 (Ford), 1980 (Carter), 1984 (Reagan), 1992 (Bush), and 1996 (Clinton). The dummy variable RELECT was assigned a value of 1 in those years and zero in all other years. [The 1980 election year could not be included in the analysis because of the 1980-1982 gap in the flood damage data. However, May (1985) suggested that President Carter might not have conformed to the pattern found among the other six presidents.]

When RELECT is added to the baseline model it makes a significant improvement in fit. (Model $R^{2}=0.652$; variance explained by the model increases from $57 \%$ to $65 \%$.) Analysis of covariance shows that, after adjusting for annual variations in flood damage and precipitation, there is a statistically significant difference between the number of declarations in reelection years and other years. (Adjusted mean SDECL is 5.33 in reelection years and 4.41 in other years: $F=5.92, d f_{1}=1, d f_{2}=26, p=0.022$.) The adjusted means correspond to 28.4 flood-related declarations in years when the president was running for reelection, and only 19.4 in other years, representing a $46 \%$ increase independent of damage and precipitation.

This result indicates that presidents tend to issue disaster declarations more generously in years when they are facing reelection, strongly supporting the contention that electoral politics plays a role in presidential disaster declarations.

\section{STATE CAPABILITY: FLOOD-RELATED DISASTERS AND DAMAGE BY STATE}

To qualify for major disaster assistance under the Stafford Act, a state is required to show that the disaster is of such severity and magnitude that effective response is beyond the capabilities of the state and the affected local governments. State and federal conflicts over disaster assistance have frequently centered on the level of state capability (often called a state's ability to pay), and the appropriate federal share of the costs (May 1985). A short-term view, focused on a state's immediate preparedness to respond to a present crisis, would tend to reward states that have taken little or no initiative in addressing their hazards risks. A longer-term perspective on state capability is adopted, based on the view that present capabilities are the result of past choices about how states use their resources.

Three possible indicators of a state's financial ability to cover the cost of disasters are considered: per capita damage, total damage as a percent of annual state expenditures, and per capita damage as a percent of median household income (GAO 1995). NWS estimates of flood losses in each state have been published annually since 1983 [U.S. Army Corps of Engineers (USACE) 1993, 2000]. For each state, the total inflation-adjusted flood damage (in 1995 dollars) during 1983-1997 was used.
Indicators of states' ability to pay were computed as follows:

1. Per capita damage $=$ total damage/state population in 1990

2. Damage as a percentage of annual state expenditures $=100 \times$ total damage/state expenditures in 1995

3. Per capita damage as a percentage of median household income $=100 \times$ per capita damage $/$ state average median income for 1993-1995 (in 1995 dollars)

The relationship of flood-related disaster declarations to each of these measures is indicated by the following correlations with $S D E C L$ (square root of the number of declarations):

\section{log (total damage)}

$\log$ (per capita damage)

0.57

$\log$ (per capita damage as a percentage of median 0.36 household income)

Each correlation is statistically significant; however, the number of declarations is related much more strongly to total damage than to the three indicators of ability to pay. Indeed, the correlations are about the same for the three indicators. Therefore, the simplest indicator is useddamage per capita - to summarize the results: based on $r^{2}$, total damage can explain $32 \%$ of the variance in SDECL, while per capita damage can explain only $12 \%$. Thus, the number of declarations is related most closely to total damage.

Table 3 shows total flood damage during 1983-1997, by state, for the states that rank highest in per capita damage. The total number of disaster declarations and the mean percentage of counties included are also shown. North Dakota, the top-ranked state with nearly $\$ 6,000$ of flood damage per capita, received seven disaster declarations, most of them covering a large part of the state (averaging $65 \%$ of the counties). Second-ranked Iowa, which had $\$ 2,800$ of damage per capita (and the highest total damage), received 10 disaster declarations. Far down the list, Texas suffered $\$ 166$ of damage per capita and received 15 disaster declarations, many of which covered only a small part of the state (averaging 9\% of the counties).

The above evidence suggests that, in practice, a state's ability to pay has not been a major consideration in presidential decisions about whether a disaster warrants federal assistance (based on the proxies used to measure ability to pay). Floods that inflict high total damage are likely to receive considerable media coverage, suggesting a possible explanation for the relatively strong relationship of declarations to total damage. 
TABLE 3. Total Flood Damage and Flood-Related Disaster Declarations during 1983-1997 for States Ranked Highest in Per Capita Damage

\begin{tabular}{|c|c|c|c|c|c|}
\hline Rank & State & $\begin{array}{l}\text { Per capita damage } \\
\quad(1995 \text { dollars })\end{array}$ & $\begin{array}{c}\text { Total damage } \\
\text { (millions of } 1995 \text { dollars) }\end{array}$ & $\begin{array}{c}\text { Disaster } \\
\text { declarations }\end{array}$ & $\begin{array}{l}\text { Mean percent of } \\
\text { counties included }\end{array}$ \\
\hline 1 & North Dakota & $5,988.93$ & $3,825.73$ & 7 & 64.7 \\
\hline 2 & Iowa & $2,806.93$ & $7,794.15$ & 10 & 23.7 \\
\hline 3 & South Dakota & $1,779.66$ & $1,238.65$ & 8 & 44.1 \\
\hline 4 & Louisiana & $1,630.39$ & $6,880.19$ & 14 & 21.0 \\
\hline 5 & Oregon & $1,213.86$ & $3,450.18$ & 6 & 25.9 \\
\hline 6 & Utah & 859.32 & $1,480.48$ & 4 & 33.6 \\
\hline 7 & Missouri & 825.59 & $4,224.62$ & 9 & 26.5 \\
\hline 8 & West Virginia & 777.41 & $1,394.28$ & 7 & 27.8 \\
\hline 9 & Mississippi & 651.79 & $1,677.19$ & 10 & 21.1 \\
\hline 10 & Nevada & 545.92 & 656.10 & 3 & 27.5 \\
\hline 11 & Oklahoma & 512.50 & $1,612.12$ & 9 & 26.1 \\
\hline 12 & Kansas & 464.68 & $1,151.27$ & 3 & 23.2 \\
\hline 13 & Nebraska & 452.52 & 714.26 & 7 & 20.1 \\
\hline 14 & Arkansas & 427.38 & $1,004.65$ & 9 & 26.4 \\
\hline 15 & Minnesota & 411.56 & $1,800.59$ & 9 & 31.8 \\
\hline 16 & Illinois & 323.19 & $3,694.24$ & 14 & 15.2 \\
\hline 17 & Wisconsin & 306.87 & $1,501.13$ & 9 & 14.8 \\
\hline 18 & Arizona & 241.02 & 883.40 & 5 & 49.3 \\
\hline 19 & Virginia & 232.71 & $1,439.84$ & 8 & 15.4 \\
\hline 20 & Kentucky & 231.34 & 852.56 & 7 & 28.5 \\
\hline 21 & Vermont & 220.77 & 124.24 & 9 & 37.3 \\
\hline 22 & California & 182.19 & $5,421.91$ & 10 & 44.8 \\
\hline 23 & Idaho & 179.60 & 180.81 & 3 & 30.3 \\
\hline 24 & Washington & 170.20 & 828.30 & 14 & 26.2 \\
\hline 25 & Texas & 166.45 & $2,827.39$ & 15 & 8.8 \\
\hline
\end{tabular}

\section{DISCUSSION}

This analysis indicates that seven presidents, from Johnson through Clinton, differed markedly in declarations of major disasters and emergencies. Flood-related disaster declarations are related, in part, to flood damage and precipitation, but the significant differences between administrations are apparently unrelated to the severity of the floods.

Disaster relief legislation since 1950 has consistently tended to expand the scope of disaster responses available to the president. However, disaster declaration requests and approvals have fluctuated by administration. The following brief review discusses specific legislative and administration actions and policy positions that might explain the variations in declarations displayed in Fig. 1 and Tables 1 and 2 (May 1985; FEMA 1997; Platt 1999).

During the Nixon and Ford Administrations, disaster programs were dispersed among many federal agencies. The increase in declarations under President Nixon might be partly attributable to disaster legislation in 1970 and 1974, which authorized declarations of "emergency" to cover smaller events, expanded benefits to include assistance to individuals and families, and provided for federal funding of mitigation efforts.

President Carter launched a major reorganization that culminated in the establishment of FEMA in July 1979. Under both the Carter and Reagan Administrations, FEMA emphasized the supplemental nature of federal aid and the need to control federal costs (May 1985). Though gubernatorial requests rose during his administration, Carter was sparing in his approvals (Fig. 1). Flood-related declarations, when adjusted for the incidence of damaging floods, dropped substantially under Carter (Table 2).
Reagan Administration policy emphasized state and local responsibility. May (1985, p. 11) observed that "the prevailing trend today is restriction and cutback at least in the domestic areas of federal activity." In the early 1980s, FEMA went through frequent internal agency reorganizations and new initiatives. A multihazard approach that emphasized development of civil defense capabilities over natural hazards led to resentment among state and local officials (May 1985). Thus, a combination of federal fiscal restraint and administrative conflicts might explain the drop in both requests and approvals during the Reagan Administration (Fig. 1).

The Stafford Act in 1988 created a new hazard mitigation grant program and allowed for approval of some smaller-scale disasters. During the Bush Administration, FEMA's responses to Hurricane Hugo and the Loma Prieta earthquake in 1989 were harshly criticized, and Congress authorized studies to assess seismological risks. In 1992, FEMA again faced severe public criticism for its response to Hurricane Andrew (Platt 1999).

With urging from the Clinton Administration after the Midwest floods of 1993, Congress enacted the Hazard Mitigation and Relocation Assistance Act of 1993 (PL 103-181), which directed FEMA to place a high priority on mitigating the impacts of future natural hazard events. This was "a fundamental shift in policy: rather than placing primary emphasis on response and recovery, FEMA's focus broadened to incorporate mitigation as the foundation of emergency management" (FEMA 1997, p. xviii). The FEMA redefined its mission to be: "to reduce the risk of loss of life and property in the United States, and to protect U.S. institutions from the disastrous effects of natural and technological hazards" (FEMA 1997, p. xvii). The FEMA employed a carrot-and-stick approach, tying 
eligibility for federal disaster assistance to compliance with FEMA-approved mitigation strategies. The federal government continued to bear the brunt of costs, and Congress voted massive supplemental appropriations for disaster assistance.

The change in FEMA's mission may well have contributed to a spiraling increase in both requests and approvals of disaster declarations during the Clinton Administration. The risk-reduction mission creates an incentive for FEMA to recommend approval of declarations because, once a disaster is declared, FEMA can more easily influence local redevelopment planning and mitigation efforts. As more marginal events receive disaster designation, states are likely to apply for declarations in other marginal events, encouraged by seeing an increased likelihood of approval (Sylves 1998).

An electoral politics aspect of the disaster declaration process is demonstrated by the present analysis of election year bias, which indicates that presidents are more inclined to issue disaster declarations during reelection campaigns. In the 1990s, a large number of highly publicized natural disasters enlivened public awareness of hazards and concern for victims, undoubtedly influencing responses of both the president and Congress (Platt 1999).

Under the Stafford Act, the general criteria for approval of disaster declarations are (1) the severity and magnitude of the incident; (2) the impact of the event; and (3) whether the incident is beyond the capabilities of the state and affected local governments. In the case of floods, the first two criteria suggest extreme or unusual weather conditions that cause severe and widespread losses. During 1965-1997, the annual number of flood-related disaster declarations is correlated with precipitation and damage, indicating that the aforementioned criteria 1 and 2 were applied, at least in part; however, the differences between presidential administrations suggest that the unwritten standards of severity and impact shifted substantially. During 1983-1997, the number of declarations is related much more strongly to total damage than to any damage measure related to a state's ability to pay, indicating that criteria 3 has been largely ignored at the state level (local government capability was not examined in this study).

\section{CONCLUSION}

These findings lead to a quite different conclusion than that presented by federal officials who attributed the increase in federal disaster declarations and related disaster costs to the rise in severe weather events. Although there is evidence of increasing precipitation in the United States, there is no evidence that this is the primary cause of the increase in disaster declarations. By invoking changes in weather, officials divert attention from the role of population growth, floodplain development, national policies, and presidential discretion in contributing to trends in federal disaster costs related to floods. To paraphrase Gilbert White, while floods may be an act of God, the federal costs of damaging floods are very much the results of policy and political decisions (Task Force 1966).

The Second Assessment of Natural Hazards in the United States (Mileti 1999) highlights risk reduction and sustainable development as essential elements of disaster recovery policy. Hazards experts emphasize the crucial role of local governments and interest groups in planning and implementation of strategies to reduce or eliminate risk (Burby et al. 1999). Consistent with these views, the analysis presented in this paper suggests that it is time to rethink the close tie between disaster declarations and hazard mitigation in present federal policy. Presidential discretion without corresponding accountability may in fact place the disaster declaration process at odds with broader goals of hazard mitigation and sustainable development.

The Association of State Floodplain Managers argues that "vague and overly generous criteria for formal disaster declarations have created disincentives for citizens, local communities, and states to take responsibility for addressing their flood hazards or protecting their floodplain resource" (ASFPM 2000). One alternative would be to reserve the presidential declaration for use as originally intended: to provide emergency assistance in catastrophic situations. A clear statement of minimum levels of damage to qualify, perhaps considering state preparedness or other factors, would prevent the downward creep in its application. In nondisaster situations, federal technical and financial help in defining hazardous areas and planning sustainable development can continue to be an invaluable aid to local governments and should not be contingent upon a particular disaster declaration.

The federal government has within its authority and control an ability to dramatically reduce or expand the costs it bears for flood disasters. The disaster declaration process requires careful tradeoffs between needed assistance in disasters and positive and negative incentives that arise from the availability of assistance. The elucidation of criteria for disaster declarations, and subsequent accountability to those criteria, are important if the effects of these incentives are to be understood and managed effectively.

\section{ACKNOWLEDGMENTS}

The writers are indebted to Mike Buckley (FEMA), Ken Kunkel (Illinois State Water Survey), and Frank Richards (NWS Office of Hydrology) for data used in this study, to several anonymous reviewers for useful comments on an earlier version of the manuscript, to Jan Hopper and D. Jan Stewart for help in manuscript preparation, and to Zoe Miller for her contributions to the flood loss reanalysis project. This paper has benefited from the knowledge of flood impacts generated from two projects: NOAA \#N96AGP0451 and Electric Power Research Institute (EPRI) \#180937. The NCAR is sponsored by the National Science Foundation.

\section{REFERENCES}

Association of State Floodplain Managers (ASFPM). (2000). "Fundamental policy changes sought by ASFPM." ASFPM News \& Views, $13,1-3$. 
Burby, R. J. (1991). Sharing environmental risks: How to control governments' losses in natural disasters, Westview Press, Boulder, Colo.

Burby, R. J., et al. (1999). "Unleashing the power of planning to create disaster-resistant communities.” J. Am. Plng. Assoc., 65, 247-258.

Federal Emergency Management Agency (FEMA). (1997). Multi-hazard identification and risk assessment: A cornerstone of the national mitigation strategy, Washington, D.C.

Federal Emergency Management Agency (FEMA). (1999). "Disaster assistance: Factors considered when evaluating a governor's request for a major disaster declaration (44CFR Part 206, RIN 3067-AC94)." Federal Register, 64(No. 169), 47697-47699.

Federal Interagency Floodplain Management Task Force (FIFMTF). (1992). Floodplain management in the United States: An assessment report, Full report, Vol. 2, L. R. Johnston Associates, Washington, D.C.

General Accounting Office (GAO). (1995). “Disaster assistance: Information on declarations for urban and rural areas." GAO/RCED-95242, Washington, D.C.

General Accounting Office (GAO). (1996). "Disaster assistance: Improvements needed in determining eligibility for public assistance." GAO/T-RCED-96-166, Washington, D.C.

Heinz Center. (2000). The hidden costs of coastal hazards: Implications for risk assessment and mitigation, Island Press, Washington, D.C.

Karl, T. R., and Knight, R. W. (1998). "Secular trend of precipitation amount, frequency, and intensity in the United States." Bull. Am. Meteorological Soc., 79, 231-242.

Lins, H. F., and Slack, J. R. (1999). "Streamflow trends in the United States." Geophys. Res. Lett., 26, 227-230.

May, P. J. (1985). Recovering from catastrophies: Federal disaster relief policy and politics, Greenwood Press, Westport, Conn.

Mileti, D. S. (1999). Disasters by design: A reassessment of natural hazards in the United States, Joseph Henry Press, Washington, D.C.
National Association of State Budget Officers. (1998). "Fiscal survey of the states."〈http://www.nasbro.org/pubs/exprpt/serexec.htm〉.

National Oceanic and Atmospheric Administration (NOAA). (2000). "NOAA reports record warmth for January-March 2000, FEMA reports presidentially declared disasters have nearly doubled and costs have skyrocketed." NOAA News, 〈http://www.noaanews.noaa.gov/ stories/s412.htm $\rangle$.

Pielke, R. A., Jr., and Downton, M. W. (1999). "U.S. trends in streamflow and precipitation: Using societal impact data to address an apparent paradox." Bull. Am. Meteorological Soc., 80, 1435-1436.

Pielke, R. A., Jr., and Downton, M. W. (2000). "Precipitation and damaging floods: Trends in the United States, 1932-1997." J. Climate, 13(20), 3625-3637.

Pielke, R. A., Jr., and Landsea, C. (1998). "Normalized hurricane damages in the United States: 1925-1995." Weather and Forecasting, 13, 621-631.

Platt, R. H. (1999). Disasters and democracy: The politics of extreme natural events, Island Press, Washington, D.C.

Sylves, R. T. (1998). "Disasters and coastal states: A policy analysis of presidential declarations of disaster 1953-97.' University of Delaware, Newark, Del.

Task Force on Federal Flood Control Policy (TFFCP). (1966). A unified national program for managing flood losses, U.S. Government Printing Office, Washington, D.C.

U.S. Army Corps of Engineers (USACE). (1993). "Annual flood damage report to Congress for fiscal year 1992.” Engrg. Div., Washington, D.C.

U.S. Army Corps of Engineers (USACE). (2000). "Annual flood damage report to Congress for fiscal year 1999.” Engrg. Div., Washington, D.C.

Witt, J. L. (1998). "National Press Club luncheon speech, November 10, 1998." 〈http://www.fema.gov/library/wittspch11.htm〉. 